This item was submitted to Loughborough's Research Repository by the author.

Items in Figshare are protected by copyright, with all rights reserved, unless otherwise indicated.

\title{
Karl Polanyi on economy and society: a critical analysis of core concepts
}

PLEASE CITE THE PUBLISHED VERSION

https://doi.org/10.1080/00346764.2016.1171385

\section{PUBLISHER}

Taylor \& Francis (Routledge) @ The Association for Social Economics

\section{VERSION}

AM (Accepted Manuscript)

\section{PUBLISHER STATEMENT}

This work is made available according to the conditions of the Creative Commons Attribution-NonCommercialNoDerivatives 4.0 International (CC BY-NC-ND 4.0) licence. Full details of this licence are available at: https://creativecommons.org/licenses/by-nc-nd/4.0/

\section{LICENCE}

CC BY-NC-ND 4.0

\section{REPOSITORY RECORD}

Hodgson, Geoff. 2019. "Karl Polanyi on Economy and Society: A Critical Analysis of Core Concepts". figshare. https://hdl.handle.net/2134/35771. 


\title{
Karl Polanyi on Economy and Society: A Critical Analysis of Core Concepts
}

\author{
Geoffrey M. Hodgson
}

1 April 2016

To be published in the Review of Social Economy

Hertfordshire Business School, University of Hertfordshire, Hatfield, Hertfordshire AL10 9AB, UK
www.geoffrey-hodgson.info
g.m.hodgson@herts.ac.uk

KEY WORDS: Karl Polanyi, embeddedness, social, economic, markets, capitalism

JEL classification: B52

\begin{abstract}
This journal highlights the social aspects of economic activity. Yet the nature of the 'social' and the 'economic' are more problematic than often assumed. This article probes Karl Polanyi's depiction of the relationship between the 'social' and the 'economic' and the notion of 'embeddedness.' In his Great Transformation (1944) Polanyi associated the 'economic' with motives of material gain, while 'social' referred to norms of reciprocity and redistribution: his distinction underlined different kinds of motivation. But in a 1957 essay he addressed different kinds of institutions that engender different motives. Polanyi (1944) argued that after 1800 Britain was transformed into a market-oriented 'economic' system, based on greed and material gain. He also believed that an effective market system would be 'self-adjusting' and free of political interference, despite his important additional claim that the state was involved in its creation. Some of Polanyi's core concepts and arguments are contradictory and problematic, and need to be reconsidered.
\end{abstract}




\title{
Karl Polanyi on Economy and Society: A Critical Analysis of Core Concepts
}

\begin{abstract}
This journal highlights the social aspects of economic activity. Yet the nature of the 'social' and the 'economic' are more problematic than often assumed. This article probes Karl Polanyi's depiction of the relationship between the 'social' and the 'economic' and the notion of 'embeddedness.' In his Great Transformation (1944) Polanyi associated the 'economic' with motives of material gain, while 'social' referred to norms of reciprocity and redistribution: his distinction underlined different kinds of motivation. But in a 1957 essay he addressed different kinds of institutions that engender different motives. Polanyi (1944) argued that after 1800 Britain was transformed into a market-oriented 'economic' system, based on greed and material gain. He also believed that an effective market system would be 'self-adjusting' and free of political interference, despite his important additional claim that the state was involved in its creation. Some of Polanyi's core concepts and arguments are contradictory and problematic, and need to be reconsidered.
\end{abstract}

More than half a century has passed since his death, but the work of Karl Polanyi has not diminished in influence. ${ }^{1}$ Especially since the economic crash of 2008, Polanyi has been cited as a key critic of the 'market economy.' Many have sympathized with Polanyi's concern about the potentially destructive, destabilizing or debasing effects of an unleashed market economy. But, despite his importance, several of Polanyi's core concepts have been deployed with little further clarification concerning what they might mean.

In particular, the meanings of key terms such as 'social' and 'economic' are rarely probed further in Polanyian discourse. Generally they are far too often taken for granted. Sociologists have defined the 'social' in various ways, but there is no current consensus on the meaning of the term, or on how it differs from the 'economic'. The philosopher John Finnis (1980, p. 135) rightly asked: 'Who has not noticed the peculiar vagueness of the term "social"?' The regrettable answer, it seems, is 'too many'. Similarly, the word 'economic' has perennial ambiguities.

\footnotetext{
1 The author is very grateful to Bas van Bavel, Fred Block, Deirdre McCloskey, Wolfgang Streeck, anonymous referees and others for valuable critical comments on earlier drafts of this paper.
} 
Generally, the lack of inter-disciplinary conversation between economics and sociology has hindered such tasks of conceptual clarification. We need to consider more carefully the meanings of widely-used and taken-for-granted words.

Even sympathizers have noted some of the conceptual and analytical problems in Polanyi's work. ${ }^{2}$ Among others, Gareth Dale (2010, p. 246) wrote that his argument concerning 'how economies are "embedded" in societies ... lacks precision.' Fred Block and Margaret Somers (2014, pp. 91, 94) noted the 'inconsistencies' and the 'ambiguities in his discussion of embeddedness' in The Great Transformation. They pointed out that Polanyi was under professional and political pressure to complete the book quickly.

Even more critically, the sociologist Isaac Martin (2015, p. 163) opined that the book is 'a mess' and 'conceptually sloppy' with several key terms undefined. Other terms are defined 'and then used willy-nilly, as if Polanyi forgot what he said the words meant.' These problems are not confined to the slippery concept of embeddedness. The serious conceptual flaws in Polanyi's work have still so far received insufficient attention. They are a barrier to the development of the still-viable parts of his approach.

A detailed textual analysis of key passages in Polanyi's work is essential to try to ascertain his intended meaning of prominent terms. After his classic work on The Great Transformation (1944), he attempted to clarify some key concepts and ideas, particularly in a later essay on 'the economy as instituted process' (Polanyi et al. 1957, pp. 243-70; reprinted in Polanyi 1968). In the process some of their meanings shifted. The analysis here is mostly confined to these two works.

Much previous criticism of Polanyi's argument has centred on his claim that markets played a marginal role in economic systems prior to the nineteenth century. Subsequent scholars have claimed that markets and prices had a substantial economic influence in ancient civilizations such as in Rome and Babylonia. But these criticisms do not overturn the importance of a shift from a non-market to a market system. If markets are defined, following Polanyi, as organized forums of exchange, rather than trade in general, then they have existed for no more than a few thousand years (Hodgson 2015a). Other forms of commodity exchange appear much earlier. But if market-driven systems are older than Polanyi sometimes suggested, we still need to identify key changes that occurred with the 'transformation' from a mostly custom-driven to a largely market economy.

These issues of historical timing are important but secondary to the main argument here, which is primarily conceptual - largely about the meaning of words and the grounding of analytical claims. There are other important aspects of Polanyi's work - such as his views on socialism - that are omitted. Instead the focus is on core concepts and analytical claims, primarily in his famous work on The Great Transformation.

This article is organized in seven subsequent sections. Section 1 considers Polanyi's uses of the terms 'economy' and 'economic' - it is shown that he often associated these words with the self-interested motive of material gain, as well as with the system of material production. By contrast 'social' referred to other kinds of motive. Section 2 outlines Polanyi's view of the nature of the transformation of society into a market economy, bearing in mind his usage of key terms. Section 3 involves a critical analysis of his claims concerning pre-transformation, 'socially embedded' economies. Section 4 considers the subsequent discourse on

\footnotetext{
2 For other forceful criticisms see Hann and Hart (2009). Holmes (2012) gives a useful overview. An earlier critique is Sievers (1949).
} 
'embeddedness.' Section 5 addresses Polanyi's claim that land, labour and money are not commodities. Section 6 addresses markets and considers Polanyi's proposal that they are essentially self-regulating. Section 7 concludes the essay and considers some ways in which some of Polanyi's important conclusions may be salvaged and rebuilt.

I must forewarn the reader that, while I do believe that there are insights to be salvaged from Polanyi's work, it is far beyond the scope of this essay to attempt a reconstruction of his thought. My primary objective is to persuade the reader of the necessity of such a task, by pointing to the definitional and conceptual problems that lie at the core of his work. Hence this essay is primarily about textual and conceptual analysis, not theoretical reconstruction.

\section{Polanyi's uses of the terms 'economic' and 'social'}

Some distinctive terms pervade Polanyi's writing. But often they lack clear definition and their intended meaning must be extracted by textual analysis. Consider the following revealing passage from The Great Transformation (Polanyi 1944, p. 46):

The outstanding discovery of recent historical and anthropological research is that man's economy, as a rule, is submerged in his social relationships. He does not act so as to safeguard his individual interest in the possession of material goods; he acts so as to safeguard his social standing, his social claims, his social assets.

So far, the intended meaning of the word 'social' is unclear. But, as Polanyi continues, it is contrasted with other attributes:

He values material goods only in so far as they serve this [social] end. Neither the process of production nor that of distribution is linked to specific economic interests attached to the possession of goods; but every single step in that process is geared to a number of social interests which eventually ensure that the required step be taken. Those interests will be very different in a small hunting or fishing community from those in a vast despotic society, but in either case the economic system will be run on noneconomic motives.

Here in a nutshell is Polanyi's proposal that the economy has been 'submerged' or 'embedded' in 'social relationships'. Note first that Polanyi uses the term 'economic' in at least two very different ways. Even in the above extract, the terms 'economic system', 'economic interests' and 'economic motives' rely on multiple meanings of their shared adjective.

Polanyi (1944, p. 30) himself noted this ambiguity in the word 'economic'. He argued that while nineteenth century industrial society rested on 'economic foundations.' It was also 'economic in a different and distinctive sense, for it chose to base itself on a motive only rarely acknowledged in the history of human societies, and certainly never before raised to the level of a justification of action and behaviour in everyday life, namely gain. The selfregulating market system was uniquely derived from this principle.'

Hence one meaning of 'economic' in several passages of The Great Transformation concerns behaviour motivated by gain (Polanyi 1944, pp. 30, 41, 46, 49, 53, 268, 269). 'Economic' here refers primarily to a type of motivation: it does not refer to an outcome, a sphere of society, or a type of analysis.

The second meaning that Polanyi sometimes attributed to 'economic', particularly when conjoined with other words such as 'foundations' or 'system', concerned that which gives rise 
to the production or distribution of material goods. The word 'economy' is often deployed in this sense in ordinary language, and by some (but not all) economists. Polanyi (1944, pp. 5, $10,17,19$, etc.) frequently adopted this usage.

His 1957 essay also noted two meanings of the word 'economic.' But here the distinction is between 'the substantive and the formal meaning. The substantive meaning derives from man's dependence for his living upon nature and his fellows ... [hence] supplying him with the means of material want satisfaction. The formal meaning of economic derives from the logical character of the means-ends relationship, as apparent in such words as "economical" or "economizing", (Polanyi et al. 1957, p. 243).

First let us analyse the possible meaning of 'economic' in terms of motives of gain. We may start by asking what Polanyi considered as motives that were not to do with gain. Polanyi (1944, p. 269 - emphasis removed) wrote: 'The usual incentives to labor are not gain but reciprocity, competition, joy of work, and social approbation.' Following his association of 'economics' with the study of 'gain', Polanyi (1944, p. 47) wrote in contrast of 'two principles of behavior not primarily associated with economics: reciprocity and redistribution.' But Polanyi (1944, p. 272, emphasis removed) went on to suggest: 'Reciprocity and redistribution are principles of economic behavior which apply not only to small primitive communities, but also to large and wealthy empires.' 3

Explaining the emblematic process in the title of his book, Polanyi (1944, p. 41) wrote: 'The transformation implies a change in the motive of action on the part of the members of society: for the motive of subsistence that of gain must be substituted.'

A problem here with Polanyi's unrefined use of the term 'gain' is that all activities, including status-seeking, reciprocity and subsistence production, could be interpreted in some way as involving gain. Consider the utility-maximizing individual that dominates mainstream economic theory. Its exponents claim that utility-maximization can cover any behaviour, including altruism and cooperation (Collard 1978, Fehr and Gächter 2000, Bowles and Gintis 2011). Utility functions can be enlarged to include 'other-regarding' or 'social' preferences. Although this all-embracing utilitarian argument can be criticized, it should be addressed. ${ }^{4}$

While Polanyi eschewed utility-maximizing interpretations of behaviour, he did not envisage this possible utilitarian riposte. Instead he left us with a few clues that by 'gain' he meant something more restrictive. As quoted earlier in this section, Polanyi (1944, p. 46) contrasted gain and 'the possession of material goods' with concerns about 'social standing ... social claims ... social assets.' Hence with 'gain' Polanyi seemed to focus on 'material goods' and their use as ends rather than means. Polanyi (1944, p. 153) also wrote:

Though human society is naturally conditioned by economic factors, the motives of human individuals are only exceptionally determined by the needs of material wantsatisfaction. ... Purely economic matters such as affect want-satisfaction are incomparably less relevant to class behavior than questions of social recognition. ... But

\footnotetext{
3 Mainstream economists centre on gain, but in terms of utility maximization, and not necessarily markets or prices. For them, 'economics' is not solely about markets, but applicable to any situation involving choice, even without market prices. For many of them, their subject is defined in terms of the tools of utility-maximization and rational choice, applied to almost any area of enquiry, including families and other 'social' domains (Robbins 1932, Becker 1976).

4 This theoretical move can be criticized on the grounds that it reduces every motivation to a matter of mere preference, whereas motivational impulses are multiple and varied (Wilson 2010, Hodgson 2013).
} 
the interests of a class most directly refer to standing and rank, to status and security, that is, they are primarily not economic but social.

This passage suggests that 'gain' meant 'material want-satisfaction' and that these are 'economic factors' and 'purely economic matters'. By contrast, 'social' factors concern 'social recognition ... rank ... status and security'. For Polanyi, the 'economic' centres on motives of 'material want-satisfaction' and the possession of goods, whereas the 'social' concerns non-material motives including social esteem, rank and status.

Polanyi's 1957 essay was conceived precisely as an attempt 'to determine the meaning that can be attached with consistency to the term 'economic' in all the social sciences.' A significant shift occurs. Instead of motives alone, Polanyi then widened the focus to include the institutional conditions that give rise to particular kinds of motive. Hence he saw the market economy as 'embodied in institutions that cause individual choices', and involving a 'rational' assessment of means and ends, on the basis of prices. This implied an interpretation of the 'economic' as not simply about greed and gain, but also about the market institutions that allegedly promote these self-interested and calculative motives. But if markets themselves do not function solely through greed, then markets may harbour elements of the 'social' too. ${ }^{5}$

We know that Polanyi read Max Weber and gave lectures on his Economy and Society (Swedberg 2011, p. 63). Weber's (1968) typology of different concepts of rationality provided him with a way of distinguishing between 'economic' and 'social action', where the former was an instrumental calculation of means for ends, and the latter involved judgments of value. A feature in common with Polanyi's approach is the shared focus on types and ends of motivation as the method of distinguishing between the 'economic' and the 'social'. But as Dale (2010, p. 109) and Richard Swedberg (2011, p. 67) have pointed out, Polanyi's categories and reasoning behind his separation between the economic and the social are different from those of Weber.

\section{Polanyi on the 'transformation of society into a market economy'}

One of Polanyi's foremost claims in The Great Transformation was that the Industrial Revolution and the growth of capitalism threatened core social relations that had welded human society together for many thousands of years. Polanyi (1944, p. 101) saw the 'transformation of society into a market economy' as occurring in the late eighteenth and early nineteenth centuries. This section summarizes Polanyi's conceptualization of these changes.

Economic historians have criticized Polanyi's claims, arguing that market societies were prominent much earlier than the nineteenth century (Hejeebu and McCloskey 1999). In particular, contrary to the claims of Polanyi et al. (1957) and Moses Finley $(1962,1973)$, Peter Temin (2001, 2002, 2006), Morris Silver (2007) and others have argued that the Roman and Babylonian Empires contained developed and interlocking markets with variable prices. The existence of many markets in Ancient Rome is undeniable (Bang 2008). The dispute

\footnotetext{
5 While competitive markets engender self-interest and pecuniary calculation, this is far from the whole story. There are arguments and evidence to suggest that markets also rely on broader moral sentiments, such as notions of justice, and may also engender some forms of cooperation (Smith 1759, 1776, Schultz 2001, Zak 2008, Hodgson 2013).
} 
concerned their role and degree of influence over the economy as a whole. The resolution of this debate depends partly on both the definition of a market and the extent to which markets dominated production and distribution. Some historians claimed that most production was used directly for subsistence. The critics responded that markets and prices still affected the system as a whole.

A secondary historical dispute surrounds Polanyi's (1944) graphic depiction of the Speenhamland Law of 1795. Contrary to the claim that it was a widespread, flawed and catastrophic last-ditch attempt to stop the expansion of markets for agricultural labour, even sympathizers such as Fred Block and Margaret Somers $(2003,2014)$ cited a large body of scholarship showing that the use of the Speenhamland system was not widespread and it did not generally depress wages. Also, as Dale (2010, pp. 83-86) pointed out, Polanyi underestimated the earlier development of wage labour in England.

Our conceptual critique of Polanyi does not hinge on the outcome of these historical disputes. Polanyi referred to a transformation of human relations that occurred when organized markets and market prices dominated production and livelihood. A similar transformation was noted by Weber. The dating of this transformation is important but secondary. More important is that it occurred. Crucially, Polanyi (1944, p. 41) characterized the emergence of the 'market system' in these terms:

The transformation implies a change in the motive of action on the part of the members of society: for the motive of subsistence that of gain must be substituted. All transactions are turned into money transactions, and these in turn require that a medium of exchange be introduced into every articulation of industrial life. All incomes must derive from the sale of something or other ...

This account of the transformation focuses on a shift in prevailing motives from 'subsistence' to 'gain', and to the dominance of money transactions. Polanyi (1944, p. 43) also focused on the role and place of markets:

No society could, naturally, live for any length of time unless it possessed an economy of some sort; but previously to our time no economy has ever existed that, even in principle, was controlled by markets. ... Though the institution of the market was fairly common since the later Stone Age, its role was no more than incidental to economic life.

Hence Polanyi argued that for much of human history, systems of production and distribution were not 'controlled by markets.' He was right on this point, especially if we adopt a definition of markets as organized arenas that generate market prices, which is narrower and more specific than trade in general. Polanyi (1944, p. 56) was clear about this: 'A market is a meeting place for the purpose of barter or buying or selling. Unless such a pattern is present, at least in patches, the propensity to barter will find but insufficient scope: it cannot produce prices.' Markets are thus defined as organized forums of exchange. By 'market' Polanyi did not mean trade in general. This is a defensible definition. The earliest evidence that we have of such markets is in China circa 3000 BC; while trade as such is much older. ${ }^{6}$

The substantial point that Polanyi pressed home was that the transition to a full 'market economy', rather than the mere existence of markets, made the motive of gain dominant. On this point his position is similar to that of Weber and others. But to understand fully Polanyi's

\footnotetext{
6 See Hodgson (2015a, pp. 132-5, 389-90) for a similar definition and information on the earliest markets.
} 
conception of the transformation we need to examine his account of pre-market systems of production.

\section{Embedded economies - before their transformation}

Polanyi cited substantial anthropological evidence to show how pre-market societies were organized. He quoted works by Ruth Benedict, Bronislaw Malinowski, Richard Thurnwald, and others. Despite manifest differences between societies, he extracted some common features. He listed motivations and structures that functioned before the dominance of markets. The foremost two of these are 'reciprocity and redistribution' (Polanyi 1944, p. 47), which refer to mutual help and sharing within close-knit groups or tribes. Polanyi's (1944, p. 53) 'third principle' was called 'householding' and 'consists of production for one's own use.' 7 Concerning these principles Polanyi's (1944, p. 49) big claim is as follows:

As long as social organization runs in its ruts, no individual economic motives need come into play; no shirking of personal effort need be feared; division of labor will automatically be ensured; economic obligations will be duly discharged; and, above all, the material means for an exuberant display of abundance at all public festivals will be provided. In such a community the idea of profit is barred; higgling and haggling is decried; giving freely is acclaimed as a virtue; the supposed propensity to barter, truck, and exchange does not appear. The economic system is, in effect, a mere function of social organization.

For our purposes, we need not contest the evidence from tribal societies in favour of this claim. But Polanyi went further, to suggest that larger economies could be organized similarly, to a large extent without markets. Polanyi (1944, p. 49) wrote: 'It should by no means be inferred that socioeconomic principles of this type are restricted to primitive procedures or small communities; that a gainless and marketless economy must necessarily be simple.' 8

Polanyi's claimed that instead of the dominance of markets and gain, modern society could be governed by principles of reciprocity and redistribution. He tried to give historical evidence to authenticate this possibility. Polanyi (1944, p. 272, emphasis removed) explained: 'Reciprocity and redistribution are principles of economic behavior which apply not only to small primitive communities, but also to large and wealthy empires.' Polanyi then (1944, pp. 50-52) gave examples from ancient Egypt to feudal Europe of large-scale redistribution, involving systems of taxation.

\footnotetext{
7 Note that in his 1957 essay Polanyi dropped the concept of 'householding' and replaced it by 'exchange' (Polanyi et al. 1957, p. 250). The other two categories remained. This indicated that 'exchange' was a much more long-lasting feature of human societies than his 1944 book seemed to suggest.

${ }^{8}$ Note that Polanyi (1944, pp. 234, 252) envisaged a future system with 'production ... regulated directly' and markets as 'useful but subordinate'. But while 'the end of market society means in no way the absence of markets' he wished to abolish markets for land, labour and money. Money would be no more than tokens and consequently 'markets' generally as we know them would no longer exist.
} 
Redistribution is ubiquitous in modern developed economies. ${ }^{9}$ But Polanyi gave no example of large-scale reciprocity involving millions of people, rather than clans or tribes. While he gave strong evidence for reciprocity at the tribal level, he did not demonstrate that it was central to any large-scale, complex society. His historical and anthropological evidence is thus of limited effect.

A big question is whether the principles of reciprocity, redistribution and house-holding are sufficient in large-scale societies with a complex division of labour, without a major additional role for extensive commodity exchange and numerous markets. Reciprocity is especially problematic in large-scale settings. Mechanisms of reciprocity depend on reputations and some monitoring, crucially involving much face-to-face interaction. Their effectiveness depends on a manageable number of individuals. It is well know that these mechanisms can be undermined with larger numbers of agents, simply because of the greater chances of interacting with new and unfamiliar faces (Bowles and Gintis 2011).

Some reciprocity, sharing and production for need can be found in microcosm in all societies. We have to look no further than families and small communities for substantial evidence. But at least in larger-scale, more complex societies these elemental units are not the whole story. Much production and consumption occurs outside the compass of families or small groups.

We have to consider how the social system as a whole, with a specialized division of labour, is coordinated, and what mechanisms are used to distribute the produced output from one locality to another. In large, advanced, complex societies, involving millions of people, evidence of the dominance of reciprocity and house-holding, as primary mechanisms of allocation or production, above tribal or family units, is highly limited at best.

Consider the Inca Empire of the fourteenth to sixteenth centuries, which had a high degree of central planning (McEwan 2006). Taxes were raised and markets and trade were limited. Reciprocal exchange was prominent at the local level. But much agricultural output was for subsistence. Extreme poverty was avoided, but so too was general prosperity. Income per capita was low compared to contemporary Italy or China, and much lower than in the advanced economies of the modern age. These have much more complex divisions of labour. ${ }^{10}$

Polanyi (1944, p. 46) briefly attempted an evolutionary explanation 'in terms of survival' of the supremacy of the principles of reciprocity, redistribution and house-holding. He argued that the survival of the group was vital: 'The individual's economic interest is rarely paramount, for the community keeps all its members from starving unless it is itself borne down by catastrophe.' Accordingly the 'maintenance of social ties ... is crucial', including

\footnotetext{
${ }^{9}$ Since The Great Transformation was published there has been a huge rise in taxation and welfare redistribution in developed capitalist economies. Despite large budget cuts and austerity, levels of public spending and welfare redistribution remain much higher than before the Second World War. Also they have largely held up since 1980, against claims of eroded redistribution in the era of globalization. See for example OECD data from http://stats.oecd.org/Index.aspx?datasetcode=SOCX_AGG. (Retrieved 6 March 2015.)

10 Maddison (2007, p. 382) calculated that 1500 GDP per capita figures for Mexico and South America were about two-thirds of that in China and less than half of that in Italy in the same year. US GDP per capita in 2003 was about seventy times greater than South American GDP per capita in 1500. The Inca Empire may have constituted about a third of the South American population at that time (Denevan 1992).
} 
'honor', 'generosity', and 'reciprocal' obligations. This is redolent of Charles Darwin's (1871) much more extensive account of the evolution of cooperation in social groups. ${ }^{11}$

But in pursuing this evolutionary explanation, Polanyi $(1944$, p. 46) went too far, arguing that, for an individual, considerations of survival 'must exert a continuous pressure to eliminate economic self-interest from his calculations.' Rigorous accounts of the evolution of cooperation in groups do not sustain this extreme position. While considerations of selfinterest certainly need to be restrained for group survival (by frequent altruism), the entire elimination of self-interest would be dysfunctional in evolutionary terms; it would remove all impulses to survive and leave the individual vulnerable to adverse circumstances when altruism from others was interrupted for some reason (Bergstrom 2002). The literature on the evolution of cooperation also shows that behaviour that benefits both the actor and others can evolve more easily than behaviour that benefits others, but without any positive advantage to the actor (Bowles and Gintis 2011, Okasha 2013). Polanyi's evolutionary argument rightly stresses group survival, but wrongly suggests that evolution would eliminate self-interest, even in groups.

Polanyi consistently underestimated the problems of scale and complexity, by assuming that the interpersonal relations and reciprocity found in smaller communities can be readily expanded to large, modern, complex societies. In 1925 Polanyi $(2000$, p. 317) wrote in a letter to a friend of 'aiming at making society as transparent as a family's life', without any recognition of the problem of limited general interpersonal intimacy in large-scale contexts.

In sum, Polanyi gives us no reason or evidence to presume that a large-scale, complex, developed economy is possible without some pursuit of self-interest and considerable use of markets. The principles of reciprocity, redistribution and house-holding are insufficient, notwithstanding their enduring presence. Additional mechanisms are required to make developed large-scale economies work.

\section{Getting in and out of embeddedness}

Polanyi's use of the term 'social' must be appraised in the light of the above considerations. While Polanyi admits that the term 'economic' has two meanings (referring to the system of production and the motive of gain), for him the 'social' refers to motives and arrangements in terms of reciprocity, redistribution and house-holding, in opposition to material gain.

What can be made of statements by Polanyi (1944, p. 57) concerning the 'economy being embedded in social relations' (in pre-market societies)? This is the touchstone for the burgeoning and influential literature on 'embeddedness' (Granovetter 1985, Lie 1991, Mendell and Salée 1991, Krippner 2001, Gemici 2008). Yet while the concept of 'embeddedness' is by some regarded as central to the work of Polanyi, and by others as a core concept in modern economic sociology (Swedberg 1993, 1996, 2005, Krippner 2001), it is rarely defined clearly.

For example, Phil Cooke's (2007) article is one of the few in this journal that has the term 'embeddedness' in its title and much of its content, but the reader will search in vain within for a definition of the term. Instead, and typically, there is much hand-waving in the direction

\footnotetext{
11 Such 'group selection' arguments used to be regarded as flawed, but they have been rescued by recent sustained scholarship (Sober and Wilson 1998, Bowles and Gintis 2011, Hodgson 2013).
} 
of Mark Granovetter's (1985) classic article, but without much additional conceptual clarification.

Contrary to an impression gained from some of this literature, Polanyi did not use the term 'embedded' very often in his famous book. It appears only six times in The Great Transformation, and 'embeddedness' has not been found there at all." ${ }^{12}$ Polanyi (1944, pp. 46, $52,67,68)$ also makes statements such as the 'economic system was submerged in general social relations', and uses additional terms such as 'enmesh,' 'absorb' or 'contain' to describe the relationship between the 'economic' and the 'social'.

Polanyi's low-frequency usage of terms such as 'embedded' does not mean that the intended, underlying ideas are unimportant for him. After all, as noted above, he had an armoury of additional terms that suggest similar meanings. For example, Adam Smith used the term 'invisible hand' very rarely, but this does not mean that his notion of undesigned order was anything less than central for much of his narrative. But the problem for Polanyi is that, whatever term he used, the nature of, and relationship between, the 'social' and 'economic' is far from obvious. It is often passed over by commentators on The Great Transformation, who seem to assume that these things are clearly defined.

It has been argued in this essay, that for Polanyi (1944) his reference to 'economic' and 'social' was primarily to two different kinds of motivation and to concordant relations based upon them, in the first case concerning material gain, and in the second case concerning such factors as 'rank ... status and security' within a framework involving reciprocity and redistribution. Given Polanyi's use of these terms, an observation concerning an 'economy being embedded in social relations' might signal a primary assertion that material production and distribution are entangled with relations and motives concerning rank, status and security. Later Polanyi (1968, pp. 306-8) wrote of movements of the ownership and location of goods being 'embedded' in 'social relations'. The first major problem here is that it is difficult to conceive of a society where this is not the case. All market economies rely vitally on social relations as much as other economies.

Polanyi (1944, p. 57) made an additional claim concerning the market economies that emerged after 1800: 'Instead of economy being embedded in social relations, social relations are embedded in the market system.' Given Polanyi's own terminology, this seems to indicate a reverse outcome, where relations concerning rank, status and security, are surrounded by trade, powered by motives of material gain. Hence motives and relations other than for material gain continue to exist in a market economy, despite the prominence of motives of gain. Claims concerning persistent mixed motives had already been made by other writers, but Polanyi made little of them. ${ }^{13}$

In his detailed analysis of Polanyi's texts, Dale (2010, p. 193) concluded that 'Polanyi's use of the term "embeddedness" can appear indistinct, or beset by contradiction. ... Polanyi's use of the term tends to drift towards the commonplace that "the economy is embedded in

\footnotetext{
12 Maucourant and Plociniczak (2013, pp. 516-17) claimed that 'Polanyi used the term "embeddedness" only twice in The Great Transformation'. They do not give page references and I have been unable to find these appearances. I shall stand corrected if they exist. Maucourant and Plociniczak (p. 517 n.) usefully cite appearances in Polanyi's other works.

13 The important claim that the motives of actors involve moral as well as money-seeking dimensions, even within the pecuniary culture of modern capitalism, is prominent in the present journal (e.g. Stikkers 1993) and in the similarly-titled 'socio-economics' founded by Etzioni (1988).
} 
institutions." If so, other historical school and institutionalist scholars had reached this point long before, and the notion of 'disembeddedness' was severely problematized.

Block (2003) among others has tried to modify Polanyi's message at this point. While attempting to retain the remainder of the Polanyian argument, Block argued that economies are 'always embedded' in social relations. Notably this jars against Polanyi's statement (1944, p. 57) that in a market society 'social relations are embedded in the market system' and Polanyi's (1968, pp. 26-37, 59-77) vague and repeated suggestion that markets can somehow be disembedded. Block's 'always embedded' formulation is more plausible, even if it raises further questions. ${ }^{14}$

There are obvious contrasts between the focus by most (but not all) economists on utilitymaximization and the deeper probing by sociologists into matters of values, beliefs and interpretations of meaning. In part this contrast derives from Weber (1968), as noted above. In addition, aware of Lionel Robbins's (1932) new definition of economics (as the examination of the logical relationships between means and given ends), Talcott Parsons (1937, p. 768) defined sociology as 'the science which attempts to develop an analytical theory of social action systems in so far as these systems can be understood in terms of the property of common-value integration.' Sociology was thus defined as the study of an aspect of the socioeconomic system, thereby focusing on values and beliefs. But Parsons's influence has waned in sociology and there has been growing criticism by economists of Robbins's approach.

It is difficult to avoid the suggestion that when Mark Granovetter (1985) and others brought their versions of the term 'embeddedness' to prominence it was a convenient talisman for 'economic sociology' because it linked the concerns of both economists and sociologists in relevant domains of enquiry. But otherwise no clear consensus emerged on the definition of 'economic sociology' as an approach (Hodgson 2008). Eventually, the highlighted discourse on embeddedness became a burden rather than an asset.

The political scientist James Booth (1994, p. 662) argued: 'The embedded/disembedded conceptual framework obscures the character of market society by ... insisting on too radical a detachment of the modern economy from its sustaining institutional and normative nexus.' The leading economic sociologist Neil Fligstein (1996, p. 656) reported that the 'empirical literature has failed to clarify the precise nature of social embeddedness.' Granovetter himself wrote: "I rarely use "embeddedness" any more, because it has become almost meaningless, stretched to mean almost anything, so that it therefore means nothing' (Krippner et al. 2004, p. 113). Partly because of its dependence on ill-defined terms, the discourse on embeddedness has largely reached a dead end.

14 See also Block and Somers (2014). Note Block's downgrading of the word capitalism and of the key modern role of financial institutions. Block (2003, p. 281) wrote: “capitalism" is used very sparingly in the GT [Great Transformation]. Most of Polanyi's references to capitalism in the book occur when he is discussing other sources that use that term. In constructing his own argument, he carefully employs the term "market society" instead of capitalism.' These claims by Block are invalid. First, inspection of the text shows that it is untrue that 'Polanyi's references to capitalism in the book occur when he is discussing other sources that use that term.' Second, Block was wrong to suggest that the term 'capitalism' is 'used very sparingly' in the Great Transformation. In fact 'capitalism' appears 48 times, 'capitalistic' 17 times, 'capitalist' (or derivatives but excluding 'capitalistic') 32 times. Block's (2012) preferred terms of 'market economy', 'market society', and 'market system' appear respectively 96, 18, and 49 times. They denote very different phenomena. While markets (in the sense of organized forums of exchange) have existed for a few thousand years, economic systems dominated by banking, finance and money capital emerged in Italy in medieval times and became more developed in Britain in the eighteenth century (Streeck 2012, Hodgson 2015a). 


\section{More havoc: Polanyi on commodities}

Before we consider further Polanyi's views on markets, we address his peculiar treatment of the commodity. Apart from 'embeddedness' no other Polanyian concept has caused such havoc. In a crucial passage, Polanyi (1944, p. 72) wrote:

Commodities are here empirically defined as objects produced for sale on the market ... But labor, land, and money are obviously not commodities; the postulate that anything that is bought and sold must have been produced for sale is emphatically untrue in regard to them. Labor ... is not produced for sale but for entirely different reasons ... land is only another name for nature, which is not produced by man; actual money, finally, is merely a token of purchasing power which, as a rule, is not produced at all, but comes into being through the mechanism of banking or state finance. None of them is produced for sale.

It is not clear why Polanyi declared here that labour, land and money were 'obviously not commodities'. Although he made it elsewhere, here he was not making a normative statement that labour, land and money should not be commodities. Here he was making a descriptive or analytic statement, based on an attempted definition of a commodity. Something in the nature of labour, land and money meant that they were not commodities. Whatever he meant, it is shown below that Polanyi repeatedly contradicted his statement that land and money were 'obviously not commodities'.

Others treat the matter as straightforward. Block (2001, p. xxv) wrote: 'For Polanyi the definition of a commodity is something that has been produced on a market ... land, labor, and money ... were not originally produced to be sold on a market.' Dale (2010, p. 50) gave a similar interpretation: 'Because human beings and nature are not produced for sale, they are not commodities'.

But an unresolved ambiguity here lies in the verb 'to produce'. Production can be intentional or unintentional. Land, for example, is produced by geological and natural processes on Earth's crust, but (most of it) is not intentionally produced by humans. Some additional clarification is needed. As a best guess, Polanyi might have meant a definition of a commodity as a good or service produced intentionally for eventual contractual exchange. This suggests a definition of a commodity involving intentional production for sale. For example, a modern wage worker was not intentionally procreated for sale.

But a slave-owner may oblige slaves to produce offspring for sale. Labour power can be produced intentionally within a slave society. Also, in modern societies, some land can be reclaimed or improved. Why money, by this criterion, is not a commodity is unclear. Polanyi did not explain why money 'is not produced at all.'

There is a possible nugget of wisdom beneath Polanyi's clumsy language. Because they are not created intentionally for contracted exchange, the original creations of units of land and potential labour power (outside slavery) are largely or wholly independent of the market forces of supply and demand.

Karl Marx (1975, p. 365) made a similar point in 1844, when he noted that 'political economy maintains that supply and demand always balance each other' but forgets that 'the supply of people' is not in response to market demand 'and therefore the disproportion between supply and demand finds its most striking expression in what is the essential goal of production - the existence of man.' But regrettably this never became a centrepiece of his 
analysis of capitalism. Economists today describe these spheres where market forces do not operate as 'missing markets'. They have important consequences, as noted later below.

But while the original supply of land or labourers may be irresponsive to market forces because they already exist or are produced via different mechanisms - in a market economy at any point of time the actual supply (i.e. amounts offered for sale or hire) of labour or land are not independent of market signals.

Polanyi (1944, p. 76) also wrote of 'genuine commodities' and 'fictitious ones.' But the meanings of 'genuine' or 'fictitious' commodities are still obscure. In places he seemed to refer to (impossible) attempts to make a non-commodity a commodity. But this again begs the question of how a commodity is defined. ${ }^{15}$

Polanyi's vagueness was compounded by repeated self-contradiction. Polanyi $(1944$, p. 77) admitted that labour could be bought and sold: 'No market economy was conceivable that did not include a market for labor.' Polanyi (1944, p. 107) then went even further, contradicting his claim that labour was not a commodity: 'The mechanism of the market was asserting itself and clamoring for its completion: human labor had to be made a commodity.' There is no qualifying use of the term 'fictitious' here.

In 1937 Polanyi wrote of labour becoming 'a commodity to be bought and sold, like cucumbers' (quoted in Dale 2010, p. 36). Again contradicting his forceful statement of 1944, Polanyi wrote: 'The rise of the market to a ruling force in the economy can be traced by noting the extent to which land and food were mobilized through exchange, and labor was turned into a commodity free to be purchased on the market' (Polanyi et al. 1957, p. 255). This suggested that labour in particular could become a genuine commodity. Even later, Polanyi (1977, p. 10) argued: 'The crucial step was that labor and land were made into commodities; that is, they were treated as if they had been produced for sale. Of course, they were not actually commodities, since they were either not produced at all (like land) or, if so, not for sale (like labor).' All these statements defied his 1944 claim that they were 'obviously not commodities.' Against himself, he wrote that land and labour could be traded: hence they could become commodities, or be like commodities, rather than 'obviously' otherwise.

But Polanyi failed to define production clearly or explain why (intentional) production for sale was so crucial. The fact remains that under capitalism much land and labour power are traded or hired, whether or not they were intentionally produced for such contractual exchange.

The important point that wage labourers and much land are not originally produced under market conditions is better made independently. It is not made effectively by simply trying to narrow the definition of a commodity. The crucial analytical point is this: because most land, and wage labourers are not produced intentionally for sale, and the creation of much money is due to the state, it follows that land, labour and money are not fully ruled by market forces, unlike the production of other commodities. Polanyi's tactic of sometimes denying (for unclear reasons) that land, labour and money are commodities does not make this vital point.

\footnotetext{
15 Özel (1997) argued that Polanyi’s notion of 'fictitious' commodities was influenced by Ferdinand Tönnies and is close to Marx's idea of 'commodity fetishism'. But Polanyi (1944, p. 72 n.) wrote that his 'fictitious commodity' concept had 'nothing in common' with Marx's 'commodity fetishism'. Also Marx, unlike Polanyi, clearly and repeatedly saw labour, land and money as 'commodities' under capitalism. Özel also claimed that Polanyi's notion of a commodity privileges objects over relations.
} 
Polanyi further impaired understanding when he subsequently contradicted his own peculiar and unclear definition.

Further difficulties are created because the term 'commodity' is used by many others in differing ways. For instance, when economists and business people write of 'commodity markets' they often refer to traded material substances with intrinsic use-value, such as wheat or oil, rather than tokens or services. Commodities are thus seen as useful material items or substances that are destined (intentionally or unintentionally) for trade. This alternative meaning is reinforced by the commonplace term 'commodity money,' which usually refers to money made of metal, or another substance with intrinsic use-value, excluding tokens or IOUs. Unlike Polanyi, Marx did not require something to be intentionally produced for sale for it to qualify as a commodity. Instead, commodities were useful material entities or forces. Marx thus admitted land and labour power as commodities. Hence in the opening chapter of the first volume of Capital on 'Commodities,' Marx (1976, pp. 125-6) beheld within capitalism an 'immense collection of commodities.' The merits and demerits of different definitions of a commodity are considered elsewhere (Hodgson 2015a). ${ }^{16}$

But these questions of definition are secondary to any analysis why labour, land and money may be different in some respects. Definition and analysis is not the same thing. Definitions demarcate populations of types, while analyses explain causal mechanisms.

Polanyi's claim that labour, land and money are (by their nature) not commodities is unclear, contradicted by other passages in his work, and beyond the point. Instead of implicitly narrowing the meaning of the term 'commodity' he should have concentrated on, and extended, his discussion of the real-world consequences of making these items objects of commerce and trade. He should have also focused on the point that, with land and wage labourers their original supply is not typically the outcome of market forces. Hence there are 'missing markets' even within developed capitalism (Hodgson 2015a).

\section{Confusion compounded: Polanyi on markets}

Polanyi argued at length that attempts to extend the market relations, particularly the creation of markets for labour, land and money, had disastrous consequences for the survival for motives and considerations other than material gain, and for the whole social fabric. But he adds further twists to this story. Some of these additions do not help.

Among these, he repeated the notion that a market economy is essentially 'self-adjusting' or 'self-regulating'. Polanyi $(1944$, p. 41) claimed that 'the most startling peculiarity of the [market] system lies in the fact that, once it is established, it must be allowed to function without outside interference.' He gave no argument in favour of this claim. Polanyi (1944, p. 68) also wrote: 'A market economy is an economic system controlled, regulated, and directed by markets alone.' This implied a lack of political interference or regulation. As Polanyi (1944, p. 71) further explained: 'A self-regulating market demands nothing less than the institutional separation of society into an economic and political sphere.' But also in places

\footnotetext{
16 Nelson (1995) argued that wage labour is not a commodity because it is hired, rather than bought outright, as with slaves. This confines the notion of a commodity to entities that can be bought or sold in their entirety. Because slaves, under this definition, can be commodities, this does not seem to be consonant with Polanyi's general formulations concerning labour.
} 
(noted below) Polanyi stated that such a pure self-regulating market system is unfeasible. This important message is obscured by other confusing comments.

Against the claim that, in a market system, the markets 'must be allowed to function without outside interference', many economists and others, from Adam Smith (1776) onwards, have argued that the rules of property and contract that are essential to make markets work have to be sustained to some degree by the state (Galbraith 1987, North et al. 2009, Hodgson 2015a). As Dani Rodrik (2011, p. xviii) argued: 'Markets work best not when states are weakest, but when they are strong.' State involvement is unavoidable because the state is essential to sustain and enforce the laws and rights that are necessary to make market economies function, irrespective of any further state intervention to address (say) poverty or unemployment. Against this, Polanyi suggested in the above quotations that market economies require their separation from the state. Polanyi himself points to other necessary 'social' supports for a market economy. Yet in when he said that markets 'must be allowed to function without outside interference' he seemed more like a free-market libertarian. ${ }^{17}$

But against free-market libertarians, and with a more credible argument, Polanyi emphasized that moves towards entirely free markets were utopian and destructive. Right at the beginning, Polanyi (1944, p. 3) insisted 'that the idea of a self-adjusting market implied a stark utopia. Such an institution could not exist for any length of time without annihilating the human and natural substance of society; it would have physically destroyed man and transformed his surroundings into a wilderness.' Polanyi (1944, p. 73) added:

To allow the market mechanism to be the sole director of the fate of human beings and their natural environment ... would result in the demolition of society. ... Robbed of the protective covering of social institutions, human beings would perish from the effects of social exposure; they would die as the victims of acute social dislocation through vice, perversion, crime, and starvation.

Consequently, Polanyi argued that the state was obliged to clear up this mess: it had to intervene to deal with the adverse consequences of the market system. This leads to his famous idea of a 'double movement'. Hence Polanyi (1944, p. 76) wrote:

Social history in the nineteenth century was thus the result of a double movement: the extension of the market organization in respect to genuine commodities was accompanied by its restriction in respect to fictitious ones. While on the one hand markets spread all over the face of the globe and the amount of goods involved grew to unbelievable proportions, on the other hand a network of measures and policies was integrated into powerful institutions designed to check the action of the market relative to labor, land, and money. ... Society protected itself against the perils in a self-regulating market system ...

Accordingly, Polanyi brought state intervention back into the story. Its role was primarily to check the deleterious operation of the market 'relative to labour, land, and money.'

This reminds us of his claim that these three are not 'commodities,' but he failed to explain why their alleged non-commodity status was problematic for their marketization. No definition of the commodity can itself show why a market for (say) labour creates the kind of problems to which Polanyi alludes. This requires analysis rather than definition.

\footnotetext{
17 The contradiction between Polanyi's notions of the market as 'self-regulating' and, by contrast, embedded in 'social' institutions is central to Gemici's (2008) important critique.
} 
Significantly, Polanyi's 1957 essay abandoned the confusing earlier claims about 'selfadjusting' markets and argued: 'The human economy, then, is embedded and enmeshed in institutions, economic and noneconomic. The inclusion of the noneconomic is vital' (Polanyi et al. 1957, p. 250). Recollect that by 'economic' here Polanyi meant that which is structured and driven by markets. Accordingly he made a plausible claim that market economies can never be pure and always contain 'impurities' such as the state and the household. ${ }^{18}$

Crucially, Polanyi gave no detailed historical explanation of why the transformation to a market economy occurred (Booth 1994). If the general principles of reciprocity, redistribution and householding were so deeply ingrained and enduring for thousands of years, then why should a system begin to uproot them and lurch toward a market economy? The only likely explanation is political: some group gained influence or power and began the process. In an important passage, Polanyi (1944, pp. 139-41) hinted at the role of the state in creating a market system:

There was nothing natural about laissez-faire; free markets could never have come into being merely by allowing things to take their course ... laissez-faire itself was enforced by the state. ... The road to the free market was opened and kept open by an enormous increase in continuous, centrally organized and controlled interventionism. ... [T] he introduction of free markets, far from doing away with the need for control, regulation and intervention, enormously increased their range. Administrators had to be constantly on the watch to ensure the free workings of the system. Thus even those who wished most ardently to free the state from all unnecessary duties, and whose whole philosophy demanded the restriction of state activities, could not but entrust the self-same state with new powers, organs, and instruments required for the establishment of laissez-faire.

But this highly plausible argument cannot easily be reconciled with Polanyi's (1944, pp. 41) other claims that the market economy is necessarily self-regulating and 'must be allowed to function without outside interference.' And if Polanyi was right in pointing to political forces behind the transformation, then the next and unfinished task of explanation is to answer why these political forces became sufficiently powerful to change society in such a radical way.

\section{Conclusion: an agenda for salvaging Polanyi}

The very title of The Great Transformation signals an assault on ahistorical social science. As Dale (2010, p. 248) points out: 'Historians would be rash to ignore his admonition against projecting the "market mentality" onto non-market and ancient societies' while orthodox economists 'can learn much from his critique' because their approach 'fails to appreciate the historical specificity of the modern market system.' To rebut Polanyi it is insufficient to show that the market economy is much older than he suggested. That is not the main point. On the long historical road involving globalization and huge technological advances, there have been several major transformations in structures, institutions and cultural norms, including those that led to modern capitalism.

\footnotetext{
18 Dale (2010, p. 73) noted the ambiguities in Polanyi's notion of the market economy. The shift in its meaning from 1944 to 1957 was analysed further by Randles (2007). See Hodgson (1988, 2015a) on 'impurities.' Schumpeter (1942) among others made a similar argument about the dependence of a market economy on nonmarket supports.
} 
This part of Polanyi's message remains highly relevant. But the general point about the historical specificity of the modern socio-economic system is by no means original to Polanyi. A century before Polanyi's classic, the founders of the German historical school made the same point, and the original American institutionalists developed these themes (Hodgson 2001). Polanyi was aware of (at least some of) these precursors. ${ }^{19}$

Another problem - and here Polanyi's critics hit the target - is that by focusing on the general growth of markets, Polanyi downplayed the emergence of key institutions that powered the eighteenth-century transformation into a capitalist economy. Both John Commons (1924) and Joseph Schumpeter (1954) saw the development of financial institutions - rather than markets in general - as crucial in this regard. By contrast, Polanyi gave more emphasis to the extension of markets, not the growth of specific financial institutions as the grounding of capitalism.

Polanyi's insistence that the growth of markets changes the character of human motives and endeavours remains highly relevant today. Instead of mixed and diffuse motivations, often dependent on customary arrangements, the market economy prioritizes pecuniary gain and calculative rationality. ${ }^{20}$ But these points too had been made earlier by Weber (1968), Schumpeter (1942) and members of the German historical school.

Perhaps part of the attraction of Polanyi's writing lies in its ostensible attempt to link the 'economic' with the 'social' and hence to create an interdisciplinary dialogue between economics and sociology. He thus appeals to critical economists and to broad-minded sociologists. But a closer look at his analysis reveals ambiguities of language and problems of interpretation in this area.

In particular, Polanyi has a 'too-pinched conception of the economic' (Booth 1994, p. 659), where 'economic' motives are exclusively to do with material gain and 'the economy' is regarded as solely about material production. Many economists, both orthodox and heterodox, would reject these overly-narrow depictions.

A valiant attempt to rescue part of Polanyi's argument from its terminological ambiguities and internal contradictions lies in Block's (2003) notion of an 'always embedded' economy. But Block was insufficiently clear what he meant by 'economy' and the nature of the 'social' in which it is allegedly embedded. These problems endure in the major book on Polanyi's significance in the age of market fundamentalism (Block and Somers 2014).

One way of interpreting this 'always embedded' claim is that agents generally have mixed motives, combining elements of self-interest with more altruistic and other concerns. This interpretation would follow from Polanyi's (1944) definitions of 'economic' and 'social' in terms of motives.

19 The growth and extent of Polanyi's knowledge of the German historical school and American institutionalism is a matter for future research. Clearly he was familiar with works by Weber and the historical school before he left the Continent and came to Britain in 1933. But it seems likely that Polanyi's deeper knowledge of American institutionalism came after he obtained a position at Columbia University in New York in 1947.

20 The normative issues here - which are not the subject of this present essay - are more complicated than some supporters of Polanyi suggest. While the attempted commodification of everything would have deleterious consequences (Satz 2010, Sandel 2012), the installation of some rights of ownership and trade (excluding slavery) can also imply some degree of formal equality under the law, and involve a move away from a world governed principally by hierarchy, status and conservative custom (Booth 1994). 
This mixed-motives claim is plausible. Although it was eclipsed by the narrow focus in much of economics on self-interest for much of the last 200 years, the idea of mixed motives was forcibly articulated by Adam Smith (1759). The idea endured within economics, as in the once-influential work of Gustav Schmoller (1900). Furthermore, working within a utilitymaximization framework, several economists have more recently argued that it is consistent with altruism and other-regarding behaviour (Collard 1978, Fehr and Gächter 2000, Bowles and Gintis 2011).

Polanyi's Aristotelean critique of utilitarianism becomes relevant here (Polanyi et al 1957, pp. 65-7, 80-3). Michael Hechter (1981) rightly argued that Polanyi's attempted demolition of utilitarianism would not necessarily undermine the case of laissez-faire: laissez-faire has been defended by several authors on non-utilitarian grounds. But Polanyi's critique can be reformulated as a rejection of the explanatory reduction of all varied human motives to the singular framework of utility-maximization (Hodgson 2013).

Another consequence of the 'always embedded' formulation is to reject Polanyi's untenable claim that markets, when they exist, must be always be 'self-regulating' and free from interference. The claim that markets are always tied up with the 'social' suggests that the choice shifts from acceptance or rejection of the 'pure' market to consideration of the relative merits of different kinds of context into which markets must be 'embedded'. Instead of a general assault on the market system, we have a choice between different kinds of market economy, different degrees of market dominance, different ways of holding markets in check, and different ways of dealing with the problems markets may exacerbate or create.

This broad line of argument is closer to Polanyi's 1957 essay than his 1944 book, and it offers much more fertile grounds for future theoretical development. This is the territory that Block and Somers (2014) occupy and develop, but without giving enough attention to the deep conceptual confusions in the 1944 book.

Polanyi's insistence that the market economy was a political creation is an important counter to the libertarian view that markets are essentially an eternal and entirely spontaneous order. ${ }^{21}$ Close examination of the nature and legal foundation of key components of the market economy, including property rights and money (Commons 1924, Ingham 2004, Hodgson 2015a, 2015b), means that the state plays a key role in the genesis and sustenance of these fundamental institutions. As Dennis Searcy (1993, p. 219) put it in his critique of Polanyi: 'the market continues to operate as a political phenomenon sustained by the interests of what remain essentially capitalist states and social structures.'

Although the view of the state as necessary to help constitute the core of any developed market economy is different from Polanyi's, a similar conclusion is reached concerned the necessary intervention of the state in the market economy. The state is there not simply to curb the excesses of the modern market economy - as Polanyi argued - but to help constitute its very existence.

It has been noted above that Polanyi regarded land, labour and money as special in some sense, but his reasons for doing so were unclear and underdeveloped. It has also been suggested above that land and labour do have the shared feature that they are often not intentionally produced for sale. Outside a slave economy, children are neither produced nor bred for sale on the market. The motives for the production of potential labour power are largely beyond matters of profit. In addition, with a system of wage labour, there are limits on

\footnotetext{
21 Stiglitz (2001) underlines this important point in his Foreword to The Great Transformation.
} 
markets for future labour. Likewise, most land (except reclaimed or improved land) is bestowed by nature, rather than by market forces.

It follows that the market economy cannot be entirely self-regulating, because there cannot be complete markets for everything. Hence Polanyi referred to the unattainable 'utopia' of the fully-marketized economy. ${ }^{22}$ But instead of highlighting the notion of a 'self-regulating' market economy, Polanyi should have underlined the impossibility of complete markets for everything, and made even more of the important fact that markets cannot entirely regulate themselves. It has been demonstrated by economic theorists that the very existence of missing or incomplete markets means that attempts to extend further the role of markets do not necessarily improve efficiency (Lipsey and Lancaster 1956, Hart 1975, Magill and Quinzii 1996, McCloskey 1997, Hodgson 2015a). Polanyi's thesis can be given stronger substance.

Polanyi's (1957) broad notion of 'the economy as instituted process' remains as relevant today as when it was written. Institutions are the stuff of all economic and social life. They rely on complex motivations and interactions that are at the centre of much cutting-edge research in economics and other disciplines. But this is the beginning rather than the end of the institutional story.

While Polanyi's own arguments on the limits of the market economy are flawed, some of his lines of argument can be rebuilt on different foundations, using modern institutional analysis. Some of the conclusions from this modified analysis will differ from some of Polanyi's, but there is an important shared and historically-oriented narrative concerning the limits of commodification, privatization and marketization, even within a capitalist economy.

\section{References}

Bang, Peter Fibiger (2008) The Roman Bazaar: A Comparative Study of Trade and Markets in a Tributary Empire (Cambridge: Cambridge University Press).

Becker, Gary S. (1976) The Economic Approach to Human Behavior (Chicago: University of Chicago Press).

Bergstrom, Theodore C. (2002) 'Evolution of Social Behavior: Individual and Group Selection', Journal of Economic Perspectives, 16(2), Spring, pp. 67-88.

Block, Fred (2001) 'Introduction' to Polanyi, Karl (2001) The Great Transformation, revised edition (Boston: Beacon), pp. xviii-xxxviii.

Block, Fred (2003) 'Karl Polanyi and the Writing of The Great Transformation', Theory and Society, 32(3), June. pp. 275-306.

\footnotetext{
22 Block and Somers (2014, p. 99) wrote: 'Where Polanyi is utterly original is in his startling claim that the selfregulating market ... is a utopian idea.' This is contestable. Several leading economists have pointed to the limits to markets and their vulnerability to breakdown. Adam Smith $(1759,1776)$ argued that the market system relied on supports from government, as well as on doses of justice and morality to restrain self-interest. As noted above, Marx (1975, p. 365) saw limits to the self-regulating forces of supply and demand. Above all, J. M. Keynes (1936) attacked the notion of the self-righting and self-regulating market in his General Theory.
} 
Block, Fred (2012) 'Varieties of what? Should we still be using the Concept of Capitalism?' Political Power and Social Theory, 23, pp.269-291.

Block, Fred and Somers, Margaret (2003) 'In the Shadow of Speenhamland: Social Policy and the Old Poor Law', Politics and Society, 31(2), June, pp. 283-323.

Block, Fred and Somers, Margaret (2014) The Power of Market Fundamentalism: Karl Polanyi's Critique (Cambridge MA: Harvard University Press).

Booth, William James (1994) 'On the Idea of the Moral Economy', American Political Science Review, 88(3), September, pp. 653-67.

Bowles, Samuel and Gintis, Herbert (2011) A Cooperative Species: Human Reciprocity and its Evolution (Princeton, NJ: Princeton University Press).

Collard, David (1978) Altruism and Economy: A Study in Non-Selfish Economics (Oxford: Martin Robertson).

Cooke, Phil (2007) 'Social Capital, Embeddedness, and Market Interactions: An Analysis of Firm Performance in UK Regions', Review of Social Economy, 65(1), pp. 79-106.

Commons, John R. (1924) Legal Foundations of Capitalism (New York: Macmillan).

Dale, Gareth (2010) Karl Polanyi: The Limits to the Market (Cambridge: Polity Press).

Darwin, Charles R. (1871) The Descent of Man, and Selection in Relation to Sex, $1^{\text {st }}$ edn., 2 vols (London: Murray and New York: Hill).

Denevan, William M. (1992) The Native Population of the Americas in 1492 (Madison, WI: University of Wisconsin Press).

Etzioni, Amitai (1988) The Moral Dimension: Toward a New Economics (New York: Free Press).

Fehr, Ernst and Gächter, Simon (2000) 'Fairness and Retaliation: The Economics of Reciprocity', Journal of Economic Perspectives, 14(3), Summer, pp. 159-81.

Finley, Moses I. (ed.) (1962) Second International Conference of Economic History, Vol. I, Trade and Politics in the Ancient World (New York: Arno).

Finley, Moses I. (1973) The Ancient Economy (Berkeley and Los Angeles: University of California Press).

Finnis, John (1980) Natural Law and Natural Rights, (Oxford: Clarendon Press).

Fligstein, Neil (1996) 'Markets as Politics: A Political-Cultural Approach to Market Institutions', American Sociological Review, 61(4), August, pp. 656-73.

Galbraith, John Kenneth (1987) Economics in Perspective: A Critical History (Boston, Houghton Mifflin).

Gemici, Kurtulus (2008) 'Karl Polanyi and the Antinomies of Embeddedness', SocioEconomic Review, 6(1), pp. 5-33.

Granovetter, Mark (1985) 'Economic Action and Social Structure: The Problem of Embeddedness', American Journal of Sociology, 91(3), November, pp. 481-510.

Hann, Chris and Hart, Keith (eds) (2009) Market and Society: The Great Transformation Today (Cambridge and New York: Cambridge University Press). 
Hart, Oliver D. (1975) 'On the Optimality of Equilibrium when the Market Structure is Incomplete', Journal of Economic Theory, 11(3), December, pp. 418-43.

Hechter, Michael (1981) 'Karl Polanyi's Social Theory: A Critique', Politics and Society, 10(4), December, pp. 399-429.

Hejeebu, Santhi and McCloskey, Deirdre (1999) 'The Reproving of Karl Polanyi', Critical Review, 13(3-4), pp. 285-314.

Hodgson, Geoffrey M. (1988) Economics and Institutions: A Manifesto for a Modern Institutional Economics (Cambridge and Philadelphia: Polity Press and University of Pennsylvania Press).

Hodgson, Geoffrey M. (2001) How Economics Forgot History: The Problem of Historical Specificity in Social Science (London and New York: Routledge).

Hodgson, Geoffrey M. (2008) 'Prospects for Economic Sociology', Philosophy of the Social Sciences, 38(1), March, pp. 133-49.

Hodgson, Geoffrey M. (2013) From Pleasure Machines to Moral Communities: An Evolutionary Economics without Homo Economicus (Chicago: University of Chicago Press).

Hodgson, Geoffrey M. (2015a) Conceptualizing Capitalism: Institutions, Evolution, Future (Chicago: University of Chicago Press).

Hodgson, Geoffrey M. (2015b) 'Much of the "Economics of Property Rights" Devalues Property and Legal Rights', Journal of Institutional Economics, 11(4), December, pp. 683709.

Holmes, Christopher (2012) 'Problems and Opportunities in Polanyian Analysis Today', Economy and Society, 41(3), pp. 468-484.

Ingham, Geoffrey (2004) The Nature of Money (Cambridge: Polity Press).

Keynes, John Maynard (1936) The General Theory of Employment, Interest and Money (London: Macmillan).

Krippner, Greta R. (2001) 'The Elusive Market: Embeddedness and the Paradigm of Economic Sociology', Theory and Society, 30(6), December, pp. 775-810.

Krippner, Greta R., Granovetter, Mark, Block, Fred, Biggart, Nicole, Beamish, Tom, Hsing, Youtien, Hart, Gillian, Arrighi, Giovanni, Mendell, Margie, Hall, John, Burawoy, Michael, Vogel, Steve, and O'Riain, Sean (2004) 'Polanyi Symposium: A Conversation on Embeddedness', Socio-Economic Review, 2(1), January, pp. 109-35.

Lie, John (1991) 'Embedding Polanyi’s Market Society', Sociological Perspectives, 34, pp. 219-35.

Lipsey, Richard G. and Lancaster, Kelvin (1956) 'The General Theory of Second Best', Review of Economic Studies, 24(1), December, pp. 11-32.

Maucourant, Jerome and Plociniczak, Sebastien (2013) 'The Institution, the Economy and the Market: Karl Polanyi's Institutional Thought for Economists', Review of Political Economy, 25(3), pp. 512-531.

Maddison, Angus (2007) Contours of the World Economy, 1-2030 AD: Essays in MacroEconomic History (Oxford and New York: Oxford University Press). 
Magill, Michael and Quinzii, Martine (1996) Theory of Incomplete Markets (Cambridge, MA: MIT Press).

Martin, Isaac William (2015) 'Reading The Great Transformation', Contemporary Sociology, 44(2), March, pp. 163-166.

Marx, Karl (1975) Early Writings (Harmondsworth: Penguin).

Marx, Karl (1976) Capital, vol. 1, translated from the fourth German edition of 1890 (Harmondsworth: Pelican).

McCloskey, Deirdre N. (1997) 'Polanyi was Right and Wrong', Eastern Economic Journal, 23(4), Fall, pp. 483-7.

McEwan, Gordon F. (2006) Incas: New Perspectives (New York: Norton).

Mendell, Marguerite and Salée, Daniel (eds) (1991) The Legacy of Karl Polanyi: Market, State and Society at the End of the Twentieth Century (New York: St Martins).

Nelson, John O. (1995) 'That a Worker's Labour Cannot be a Commodity', Philosophy, 70, no. 272, April, pp. 157-165.

North, Douglass C., Wallis, John J. and Weingast, Barry R. (2009) Violence and Social Orders: A Conceptual Framework for Interpreting Recorded Human History (Cambridge: Cambridge University Press).

Okasha, Samir (2013) 'Biological Altruism', The Stanford Encyclopedia of Philosophy, Fall 2013 Edition, (ed.) Edward N. Zalta. http://plato.stanford.edu/archives/fall2013/entries/altruism-biological/. Retrieved March $10,2015$.

Özel, Hüseyin (1997) 'Reclaiming Humanity: The Social Theory of Karl Polanyi', PhD Thesis, University of Utah.

Parsons, Talcott (1937) The Structure of Social Action, 2 vols (New York: McGraw-Hill).

Polanyi, Karl (1944) The Great Transformation: The Political and Economic Origins of Our Time (New York: Rinehart).

Polanyi, Karl (1968) Primitive, Archaic and Modern Economies: Essays of Karl Polanyi, ed. with an introduction by George Dalton (New York: Anchor Books).

Polanyi, Karl (1977) The Livelihood of Man, ed. Harry W. Pearson (New York:Academic Press).

Polanyi, Karl (2000) 'Letter to a Friend, 1925', in Kari Polanyi-Levitt (ed.) (2000) Karl Polanyi in Vienna: The Contemporary Significance of The Great Transformation (Montreal: Black Rose).

Polanyi, Karl, Arensberg, Conrad M. and Pearson, Harry W. (eds) (1957) Trade and Market in the Early Empires (Chicago: Henry Regnery).

Randles, Sally (2007) 'Issues for a Neo-Polanyian Research Agenda in Economic Sociology' in Mark Harvey, Ronnie Ramlogan, and Sally Randles (eds) (2007) Karl Polanyi: New Perspectives on the Place of the Economy in Society (Manchester: Manchester University Press), pp. 133-162.

Robbins, Lionel (1932) An Essay on the Nature and Significance of Economic Science (London: Macmillan). 
Rodrik, Dani (2011) The Globalization Paradox: Why Global Markets, States, and Democracy Can't Coexist (Oxford and New York: Oxford University Press).

Sandel, Michael (2012) What Money Can't Buy: The Moral Limits of Markets (London: Allen Lane).

Satz, Debra (2010) Why Some Things Should not be for Sale: The Moral Limits of Markets (Oxford and New York: Oxford University Press).

Schmoller, Gustav (1900) Grundriss der allgemeinen Volkswirtschaftslehre, Erster Teil (München und Leipzig: Duncker und Humblot).

Schultz, Walter J. (2001) The Moral Conditions of Economic Efficiency (Cambridge and New York: Cambridge University Press).

Schumpeter, Joseph A. (1942) Capitalism, Socialism and Democracy (London: George Allen and Unwin).

Schumpeter, Joseph A. (1954) History of Economic Analysis (Oxford and New York: Oxford University Press).

Searcy, Dennis R. (1993) 'Beyond the Self-Regulating Market in Market Society: A Critique of Polanyi's Theory of the State', Review of Social Economy, 51(2), Summer, pp. 217-231.

Sievers, Allen M. (1949) Has Market Society Collapsed? A Critique of Karl Polanyi's 'New Economics' (New York: Columbia University Press).

Silver, Morris (2007 'Redistribution and Markets in the Economy of Ancient Mesopotamia: Updating Polanyi', Antiguo Oriente, 5, pp. 89-112.

Smith, Adam (1759) The Theory of Moral Sentiments; or, An Essay Towards an Analysis of the Principles by which Men Naturally Judge Concerning the Conduct and Character, First of their Neighbours, and Afterwards of Themselves (London and Edinburgh: Millar, and Kincaid and Bell).

Smith, Adam (1776) An Inquiry into the Nature and Causes of the Wealth of Nations (London: Strahan and Cadell).

Sober, Elliott and Wilson, David Sloan (1998) Unto Others: The Evolution and Psychology of Unselfish Behavior (Cambridge, MA: Harvard University Press).

Stiglitz, Joseph E. (2001) 'Foreword' to Polanyi, Karl (2001) The Great Transformation, revised edition (Boston: Beacon), pp. vii-xvii.

Stikkers, Kenneth W. (1993) 'Moral Sensibilities for the Social Economy: The Challenges Facing Social Economists in the Twenty-First Century - a Philosopher's Perspective', Review of Social Economy, 51(4), Winter, pp. 441-454.

Streeck, Wolfgang (2012) 'On Fred Block, Varieties of What? Should We Still Be Using the Concept of Capitalism?’ Political Power and Social Theory, 23, pp. 311-321.

Swedberg, Richard (ed.) (1993) Explorations in Economic Sociology (New York: Russell Sage).

Swedberg, Richard (ed.) (1996) Economic Sociology (Aldershot: Edward Elgar).

Swedberg, Richard (ed.) (2005) New Developments in Economic Sociology, 2 vols (Cheltenham, UK and Northampton, MA: Edward Elgar). 
Swedberg, Richard (2011) 'Max Weber's Central Text in Economic Sociology', in Mark Granovetter and Richard Swedberg (eds) (2011) The Sociology of Economic Life, $3^{\text {rd }}$ edn. (Boulder: Westview), pp. 62-77.

Temin, Peter (2001) 'A Market Economy in the Early Roman Empire', Journal of Roman Studies, 91, pp. 169-81.

Temin, Peter (2002) 'Price Behavior in Ancient Babylon', Explorations in Economic History, 39(1), pp. 46-60.

Temin, Peter (2006) 'The Economy of the Early Roman Empire', Journal of Economic Perspectives, 20(1), Spring, pp. 133-51.

Weber, Max (1968) Economy and Society: An Outline of Interpretative Sociology, 2 vols, translated from the German edition of 1921-1922 (Berkeley: University of California Press).

Wilson, Bart J. (2010) 'Social Preferences aren't Preferences', Journal of Economic Behavior and Organization, 73(1), pp. 77-82.

Zak, Paul J. (ed.) (2008) Moral Markets: The Critical Role of Values in the Economy (Princeton: Princeton University Press). 